\section{Marko Samardžija}

Uniwersytet w Zagrzebiu

marko.samardzija@lzmk.hr
Data przesłania tekstu do redakcji: 30.10 .2014

Data przyjęcia tekstu do druku: 10.11.2014

\title{
Gradišćanski Hrvati i gradišćanskohrvatski
}

\begin{abstract}
Aвstract: Samardžija Marko, Gradišćanski Hrvati i gradišćanskohrvatski (Burgenland Croats and Burgenland Croatian). „Poznańskie Studia Slawistyczne” 8. Poznań 2015. Publishing House of the Poznan Society for the Advancement of the Arts and Sciences, pp. 167-182. ISSN 2084-3011 .
\end{abstract}

The paper concerns the formation of the Croatian ethnic community in the Austro-Hungarian region in the $16^{\text {th }}$ century, the author tracks the development of the literary language of the Croats in western Hungary since the 1750s and monitors establishing contacts with the literary language and orthography changes in Croatia in the second half of the $19^{\text {th }}$ century. It was explained how the expressions Burgenland (Gradišće), Burgenland Croats (Gradišćanski Hrvati) and Burgenland Croatian language (gradišćanskohrvatski jezik) came to use after the first world war. The codification of Burgenland Croatian literary language is shown in 3 periods: 1 . between the two world wars; 2. from the end of the second world war to the 1970s and 3. since the end of the 1970s to the present. The main codification works (dictionaries, grammar books and orthography) in Burgenland Coratian literary language published after 1980s have been mentioned.

KeYwords: Burgenland Croats; Burgenland Croatian; language codification; Burgenland literary Croatian

Premda su se prvi osmanlijski akindžije, neregularne konjaničke jedinice (po jednima ,jurišni konjanici”, po drugima „trkači i palikuće”) u srednjovjekovnoj Slavoniji pojavili još 1391. kod Manđelosa i Morovića (u Srijemu), glavnina osmanlijskih osvajanja hrvatskih zemalja počela je nešto poslije, u XV. stoljeću pokrenuvši tada uglavnom ,unutarnje migracije" stanovništva i destruirajući hrvatski predmigracijski jezični mozaik koji je dotada oblikovan stoljećima. Nakon brojnih bitaka tijekom XV. stoljeća ta su osvajanja prvi vrhunac dosegnula 9. rujna 1493. nakon što je osmanlijska vojska teško porazila hrvatsku vojsku u bitci na Krbavskome polju, ispod tvrdoga grada Udbine. O težini toga poraza i dramatičnosti (ne)prilika što su nakon toga nastupile rječito svjedoči bolni vapaj popa Martinca (martinacb pops), „mnogo grêš'noga” hrvatskoga glagoljaškog 
pisara, u jednome brevijaru iz te 1493. godine o tome kako Turci „nalegoše na jezik [êzikb=narod] hrvatski” i ,robijahu sve zemlje hrvatske i slovinske do Save i Drave".

Nakon pada Bosne (1463.) i Hercegovine (1482.), poraz na Krbavi pokrenuo je nove migracije stanovništva, ponajprije iz neposredno ugroženih krajeva: iz Krbave, Like, Gatske, Pounja i Pokuplja. Taj veoma snažan novi val ,vanjskih migracija”, za razliku od onih koje su bile usmjerene prema talijanskoj obali Jadrana (Apulija, Abruzzi, Marke), išao je na sjever i zapad, tj. smjerom kojim su već dotada neki feudalci (Batthyányi, Erdődy, Draškovići, Keglevići, Nádasdy, Zrinski) preseljavali svoje kmetove na nove, sigurnije posjede (u Kranjsku, Štajersku, Zapadnu Ugarsku, Donju Austriju, Moravsku, Slovačku). „Najmasovnije iseljavanje Hrvata u 16. stoljeću teklo je na sjeverozapad - u zapadnu Ugarsku, Donju Austriju i Moravsku. Naseljavanje u zapadnu Ugarsku, zapravo u današnje Gradišće, započelo je poslije 1493., a svakako prije 1515., kad se na vlastelinstvu Željeznom već nalaze seljaci s hrvatskim prezimenima" (Adamček 1995: 19).

Iseljavanje je trajalo cijelo XVI. stoljeće i u njem je uglavnom i zaključeno. Išlo je na mahove (u valovima), a redovito se pojačavalo nakon brojnih poraza u bitkama s osmanlijskom vojskom ili nakon učestalih osmanlijskih provala, pljačkanja i pustošenja: nakon pada Knina, Skradina (1522.) i Ostrovice (1523.), nakon Mohačke bitke (1526.), nakon 1527. i zauzimanja Obrovca, Like i Krbave, nakon prvoga osmanlijskoga pohoda na Beč (1529.), nakon pada Požege (1537.), nakon zauzimanja Dubice (1538.), od 1541. do 1545. iz Pounja, iz Slavonije nakon pada Valpova (1543.) i Velike (1544.), nakon 1552. i zauzimanja Virovitice, nakon što je 1556. opustošena opatija Topusko i zauzeta Kostajnica, nakon pada Podzvizda (1577.), sedamdesetih i osamdesetih godina nakon pustošenja vlastelinstava Hrastovica i Steničnjak.

Mate Ujević (1934: 8-9) pretpostavlja da je seoba Hrvata u nove krajeve tekla u pet etapa: prva god. 1522.-1527.; druga god. 1532.-1533.; treća god. 1537.-1545.; četvrta god. 1556.-1561. i peta god. 1565.-1579. Kučerová (1998: 158) razlikuje tri razdoblja: prvo od početka XVI. stoljeća do tridesetih godina, drugo od tridesetih do sedamdesetih godina i treće potkraj XVI. i na početku XVII. stoljeća.

Bojevi oko Siska (1591.-1593.) u prvi su mah također potaknuli iseljavanje, ali su se te izbjeglice uglavnom vratile nakon što je osmanlijska 
vojska poražena kod Siska 22. lipnja 1593. Kako je pobjedom kršćanske vojske u Sisačkoj bitci zaustavljeno daljnje napredovanje osmanlijske vojske, u velikoj su mjeri prestala i daljnja iseljavanja hrvatskoga življa. Raniji iseljenici i naraštaji njihovih potomaka već su se udomaćili u novoj postojbini. O tome na što su nailazili u selidbi i nakon doseljenja postoji opsežna, dijelom objavljena arhivska građa (cf. Pálffi, Pandžić, Tobler 1999). „Prostor na koji su se u 16. stoljeću naselili hrvatski doseljenici stere se preko područja različitih političkih pripadnosti. Gledano povijesno bio je to zapadni pojas Ugarskog Kraljevstva sa županijama Vas, Šopron, Đura, Požun i Nitra, četvrt ispod Bečke šume i ispod Manhartsberga nadvojvodine Austrije ispod Ennsa te južni dio markgrofovije Moravske" (Breu 1995: 53). Drugačije rečeno, bilo je to područje današnjih austrijskih zemalja Burgenlanda i Donje Austrije, mađarskih županija Vas, Györ-Sopron-Moson, dijelova zapadne Slovačke (u trokutu Bratislava-Malacky-Trnava) i južne Moravske (između Drnholca / Dürnholz i Mikulova). Koliko je pak tijekom XVI. stoljeća hrvatskoga življa iselilo u spomenute krajeve, o tome u literaturi postoje različite pretpostavke i brojke: oko $60000 \mathrm{kod}$ Ujevića (1934: 9), 100000 kod Adolfa Mohla (cf. Ivšić 1937/1971: 728729), 150000 (Valentić 1970: 18) do 200000 (Valentić 1973: 15).

U literaturi se, dijelom na osnovi usmene predaje, navode različiti krajevi iseljavanja pri čem su se u ranija vremena, zbog čakavske većine među iseljenicima, često spominjali primorski krajevi. Kasnija su istraživanja pokazala da se samo manjina Hrvata iselila iz kontinentalne Dalmacije (Knin, Obrovac) ili primorja (Senj i okolica), a glavnina da je podrijetlom iz krajeva između Velebita, Kupe, Une i Save, tj. iz zapadne Bosne (Bihać, Kladuša), Krbave, Like, Gatske, Pounja, Pokuplja te iz zapadne Slavonije (kajkavci), tj. iz krajeva u kojima su do osmanlijskih provala tri od četiri osnovna hrvatska narječja (čakavsko, kajkavsko i /zapadno/ štokavsko, ikavsko-šćakavsko) tvorila bitno drugačiji (predmigracijski) jezični pejzaž od onoga koji se oblikovao nakon njihova iseljenja (cf. karte uz Ivšić 1937/1971 i Neweklowsky 1978: 281). Različito područno podrijetlo najjasnije se očituje u govorima iseljenih Hrvata što je, više usput, zamijećeno još u XIX. stoljeću (Csaplovics 1829: 25-27; Kurelac 1871). U dvadesetim godinama XX. stoljeća počinje dijalektološko proučavanje tih govora pa je dosada objavljen niz dijalektoloških radova (Vážný 1925 i 1927; Ivšić 1937/1971; Brabec 1973; Koschat 1978; Neweklowsky 1978; 
1995; 2010). Kako su pozornost dijalektologa posebno privlačile leksičke značajke tih hrvatskih govora, oblikovala se i plodna grana hrvatske dijalektne leksikografije (Palkovits 1987; Neweklowsky 1989; Tornow 1989; Balaž 1991; Vulić, Petrović 1999; Takač 2004).

Premda je još Csaplovics (1829: 11) sve iseljene Hrvate podijelio na gornje (Ober-Croaten) i donje (Unter-Croaten), danas je uobičajena razgođenija, na govorima zasnovana podjela, na Hace, Poljance, Dolince, južne čakavce (Stinjaki, Santalek), Štoje, Vlahe i kajkavce (u Vedešinu / Hedešincima i Umoku). Kako su čakavci najbrojniji, unatoč dijelom znatnim razlikama između njihovih mjesnih govora, pisani će jezik od sredine XVIII. stoljeća biti stiliziran upravo na srednjoj i sjevernoj čakavskoj osnovici.

U novoj su postojbini hrvatski iseljenici / doseljenici svoja naselja osnivali u osnovi na tri načina (opširniju tipologiju nudi Breu 1995: 50): a) doseljavanjem u postojeća naselja, b) naseljavajući pustoseline, tj. oživljavajući prostor raseljenih naselja i c) zasnivajući nova naselja koja su mogla biti ili u uređenu krajoliku ili krčevinska naselja. Jezično gledano, prvi je tip naselja dolaskom Hrvata postao dvojezičan ako su u selu živjeli samo pripadnici jedne jezične zajednice (njemačke, mađarske, slovačke ili češke), a vrlo rijetko mogao je postati trojezičan ako je naselje već bilo dvojezično, tj. ako su u naselju živjeli pripadnici dviju jezičnih zajednica, npr. njemačke i mađarske. Tako uspostavljeni međujezični dodiri dali su zanimljivih kontaktoloških rezultata na njemačko-hrvatskoj, mađarskohrvatskoj, slovačko-hrvatskoj i češko-hrvatskoj relaciji. (Za njemačkohrvatske dodire cf. Ščukanec 2011).

U novoj postojbini hrvatske su doseljenike nazivali različito: u njemačkome Croaten / Kroaten ili Krabaten / Kroboten (za koje Csaplovics [1829: 7] tvrdi da je ,pöbelhaft”), mađarski Horvátok (rjeđe i Tót), slovački Chorváti. Što se pak tiče njemačkog naziva Wasser-Kroaten / Wasserkroaten (zasvjedočen je i pisani oblik wosakrowodn; mađ. Vizihorvátok), o njegovu postanku nema suglasja: jedni sastavnicu Wasser- dovode u vezu s navodnim primorskim podrijetlom dijela hrvatskih doseljenika, drugi to tumače nastanjivanjem uz Niuzaljsko jezero (Neusidler See), a treći je izvode iz Bosna, tj. Bosner-Kroaten $>$ Bosser-Kroaten $>$ WosserKroaten $>$ Wasser-Kroaten. U Hrvatskoj su pripadnici toga dijela stare hrvatske dijaspore dugo nazivani „Hrvatima u zapadnoj Ugarskoj” („Hrvati na Ugrih"). 
U urbarima, maticama, vizitacijama, konskripcijama i drugim pisanim izvorima prisutnost je hrvatskih doseljenika, dotično njihovih imena i prezimena, kontinuirana od prve polovice XVI. stoljeća. Prisutnost u toponimiji očita je na dva načina. Rjeđe su iskonski hrvatski toponimi prešli i u jezik starosjedilaca (npr. Parapatićev Brig, njem. Parapatischberg; Podgorje, njem. Oberpodgoria; Stinjaki, njem. Stinatz, mađ. Stinác; Zajče Selo, njem. Hasendorf; mađ. Vasnyulfalva, Prisika, mađ. Peresnye). Češće je, naročito kod tzv. sestrinskih naselja, postojećemu toponimu dodan atribut kroatisch / horvát / chorvátsky, npr. Hrvatska Čenča (Kroatisch Tschantschendorf), Hrvatski Hašaš (Kroatisch Ehrensdorf), Hrvatski Židan (Horvátzsidány), Hrvatske Šice (Horvátlövó), Hrvatska Kemlja (Horvátkimle), Hrvatski Grob (Chorvátsky Grob). Na njemačkom jezičnom području dio je toponima atribuiran s Krobot- ili Krobat-: Kroboteck, Krobatischberg, Crabatendörfl, Crobotenberg, a tako i Krabatisch Jahrndorf (mađ. Horvátjárfalu, slov. Jarovce). Tako atribuirani toponimi čuvaju se dijelom i ako u naselju više ne žive pripadnici hrvatske jezične zajednice, npr. Horvátnádalja, Kroboteck. Posebno je zanimljiva hrvatska mikrotoponimija (nazivi brda, polja, predjela, šuma) na spomenutome prostoru.

O hrvatskim doseljenicima u novim krajevima vrlo brzo duhovnu su skrb preuzeli katolički svećenici koji su, bar dijelom, također bili doseljenici. Tako je već 1561. nastao Klimpuški rukopisni fragment, najstariji poznati pisani jezični spomenik hrvatskih doseljenika u zapadnu Ugarsku. Riječ je o tropismenome (zapadnoćirilično-latinično-glagoljičnom) čakavsko-kajkavskom ekavsko-ikavskom zapisu koji je na kraj latinskoga misala svoje župe, tiskana 1501. u Ostrogonu / Esztergomu, unio župnik Klimpuha (Klingenbach / Kelénpatak) Juraj Vuković (Georgius Uokoüÿcz de Jastrebarska). Uz to su ime pri kraju nalaze još dva hrvatska (prez) imena (Fÿlÿpouÿch i pop Juraÿ Symanÿch). Glavninu zapisa čine Oče naš i uskrsna pjesma Krištuš je gore ustal (podrobnije u: Tyran 2010). Po naravi stvari, Klimpuški rukopisni fragment, premda nedvojbeno važan, bio je rani individualni ostvaraj.

Nastavljača nisu imala ni protestantska nastojanja, premda je u njih bio uključen i Stipan Konzul Istranin (1521.-1579.) koji je god. 1568. u Regensburgu objavio dvosveščanu Postillu, Hrvatima na ugarsko-austrijskom prostoru namijenjen prijevod knjige propovijedi virtemberškoga teologa Johannesa Brentiusa (Jembrih 1997: 13-27). To vrijedi i za djelatnost 
„prvoga gradišćanskoga književnika” Grgura Mekinića (Georgvr Mekinich Pythiraeus; 1534.-1617.), protestantskoga pastora u Keresturu (Keresztur / Deutschkreutz) gdje je objavio dvije knjige duhovnih pjesama (Dvsevne pesne[,] psalmi ter hvale vzdania diachke, 1609. i Druge knjige dvssevnih peszan, 1611.) (opširnije u: Jembrih 1997: 39-76).

Kontinuirana pisana djelatnost među Hrvatima iseljenima u zapadnu Ugarsku i susjedne krajeve započinje zapravo od sredine XVIII. stoljeća u sklopu protureformacije i katoličke obnove. Čine je djela nabožne pismenosti čiji su autori katolički svećenici i redovnici. Ostavi li se postrani Juraj

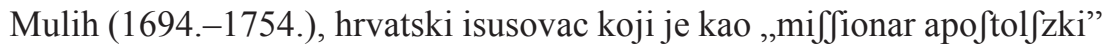
između 1730. i 1754. povremeno djelovao u zapadnoj Ugarskoj i za tamošnju hrvatsku pastvu sastavio dvije knjige (Pripravlyanye $k$-szpovidi, 1748.? i Duhovne jacske, 1750.), protagonisti su te nabožne pismenosti potekli iz zapadne Ugarske, što će reći da su bili izvorni govornici kojega od tamošnjih hrvatskih idioma, npr.: Ladislav Valentić (Valenticz): Episztole i vangyelja (Beč, 1741.), Juraj Damšić (Georgiusz Damshicz): Kratka sprava nauka kerschianzkoga (Beczko Novo Mefto, 1734.), Lovre Bogović (Laurencziuss Bogovics): Hisa zlata (Sopron, 1754.), Bogomir Palković (Godefried Pallkovics): Duhovni vertlyacz (Sopron, 1753.), Eberhard Maria Kragel: Csetvero-versztni duhovni persztan (Sopron, 1763.), Šimon Kniefac (Szimeon Knéfacz): Vrata nebészka odperta vérnom kerscseniku (Sopron, 1804.), Jožef Ficko (Fitzko): Kratak pregléd Sztaroga Zakona (Sopron, 1824.). Pisani jezik (Schriftsprache) svojih djela ti autori uzusno stiliziraju na čakavskoj, uglavnom ekavsko-ikavskoj osnovici. O jeziku te književnosti kapitalnu je monografiju objavio László Hadrovics (Hadrovics 1974; cf. i 1995), a s tom je studijom komplementaran nešto kasniji povijesni rječnik gradišćanskohrvatskoga (Nyomárkay 1996).

Važno je ovdje napomenuti da je latinični slovopis (grafija) tih djela uglavnom, tj. s mjestimičnim nedosljednostima, udešen po uzoru na mađarska slovopisna rješenja za bilježenje fonema /c/, /č/, /̌̌s/, /1̧/, /ņ/, /s/, /šs/, $/ \check{z} /$, tj. $c z, c s, g y, l y, n y, s z, \mathrm{~s}, z s$. Pravopis (ortografija) je pretežito morfonološki (,etimološki”).

Što se jezika tiče, u drugoj polovici XIX. stoljeća osjećat će se sve više utjecaj zbivanja u Hrvatskoj u kojoj je djelovanjem hrvatskih preporoditelja uveden dijakritički slovopis (,gajica”), a za osnovicu općehrvatskoga književnog jezika uzeta je štokavština. Kako je koncepcija toga jezika 
oblikovana u kritičkom suprotstavljanju triju filoloških „škola”, odjeke domovinskih zbivanja moguće je odčitati i iz nekih nastojanja vodećih ljudi među Hrvatima u zapadnoj Ugarskoj, npr. u članku Gašpara Glavanića (Kaspar Glavanich) Zabavno-poucsni Razgovor o hèrvackom pravopiszu (1865.), u jeziku i pravopisu njegove Početnice za katoličansku školsku mladost s osobitim obzirom na hérvatske škole u Ugarskom kraljevstvu (Beč, 1859.) koja će u kasnijim izdanjima mijenjati naslov (Pèrva štanka, 1860.; Pèrva čitanka, 1874. i 1882.). Izravnije od Glavanića slovopisnim pitanjima, ali i pitanjem koncepcije književnoga jezika bavio se Mihovil Naković (Nakovich), autor na Glavanićevo djelo oslonjena Podučavanja u jezikoslovlju (Eisenstadt / Željezno 1877.) i udžbenikā Zemlyopisz (1873.), Prirodopisz (1875.), Nova méra i vaga (1876.) i Ugarszka slovnica (1880.). Naković je 16. listopada 1877. u Koljnofu (Kópháza / Kohlenhof ) objavio okružnicu u kojoj izravno zagovara napuštanje ,staropisa” koji je „smrtna ura udrila” i uvođenje gajice (Črnja, Valentić, Benčić 1973: 246-247) kojom se djela počelo tiskati još od početka šezdesetih godina, a prevladala je na izmaku sedamdesetih (Benčić 1998a: 270). Usto Naković je zaslužan za pokretanje razgovora o tom trebaju li Hrvati u zapadnoj Ugarskoj i dalje njegovati vlastiti (čakavski) tip književnoga jezika (koji je tada već, i njegovim trudom, u znatnoj mjeri izgrađen kao Literatursprache) ili ga napustiti i uvesti hrvatski književni jezik ${ }^{1}$ (o književnojezičnoj koncepciji riječke filološke škole opširnije u: Vince 1978: 403-470).

Razgovori o koncepciji književnoga jezika prenijeli su se i u XX. stoljeće. Pjesnik, filozof i preporoditelj Mate Meršić Miloradić (Mersich 1850.-1928.) zagovara prihvaćanje hrvatskoga književnog jezika kao pouzdan put za spas Hrvata u zapadnoj Ugarskoj koji ,,iz vlašće snage obstati ne moru” (Benčić 1998a: 271). U tu svrhu i u tom duhu „kot pripremu za uključenje u jugoslavensku kulturu" sastavio je svoju Slovnicu hervatskoga jezika za selske škole (Győr / Djur 1919.) izrađenu u osloncu na uvod u gimnazijsku gramatiku Tome Maretića (Maretić 1899). Isto je stajalište Meršić Miloradić zastupao još 1926.: „Ako hoćemo ostat Hrvati, se moramo književno najzad pricipit našemu stablu na jugu ter tamo slati duha konči na «južinu»" (cf. Kinda-Berlaković 2011: 381).

${ }^{1}$ Sam Naković bio je, čini se, bar u morfologiji sklon hrvatskomu književnom jeziku po koncepciji riječke filološke škole. Cf. Sučić 1973: 93. 
Unatoč tomu, pokretači „družtvenog, gospodarskog i zabavnog lista” Naše novine, prvoga svjetovnog glasila Hrvata u zapadnoj Ugarskoj, čiji se prvi broj pojavio „u sabotu, 1. januara” 1910., tradiraju ustaljeni tip književnoga jezika čakavske osnovice.

Na kraju prvoga svjetskog rata Austro-Ugarska Monarhija našla se na gubitničkoj strani. Mirovni pregovori u Versaillesu vođeni su odvojeno s austrijskom i s mađarskom stranom. Austrijska je strana pritom predložila da se granica Austrije pomakne na istok, u Translajtaniju, jer da ondje govornici njemačkoga ipak čine većinu stanovništva. Sile Antante prihvatile su taj prijedlog pa je ugovorom potpisanim 10. rujna 1919. u Saint-Germaineu Austriji pripao veći dio dotadašnje zapadne Ugarske, tj. područje na kojem su Hrvati tada bili šestina stanovništva (po popisu iz 1923. od ukupno 286179 žitelja Gradišća Hrvata je bilo 42 011, tj. oko $15 \%$ ). Kako to područje dotada nije pripadalo Austriji, nije imalo ni svoj administrativni naziv. Dne 8. siječnja 1920., godinu dana prije negoli je proveden plebiscit (1921.) i nekoliko prijedloga (Heinzenland, Heidebauern, Vierburgenland, Dreiburgenland; cf. Valentić 1973: 19-20), za novu je (devetu) saveznu pokrajinu prihvaćeno ime Burgenland. (Tek 30. travnja 1925. glavnim je gradom nove pokrajine proglašen Eisenstadt / Željezno). Njemačko ime pokrajine zakratko su prihvatili i Hrvati dok Mate Meršić Miloradić nije kao hrvatski naziv predložio Gradišće prema kojem je tvoren pridjev gradišćanski. Tek tada u optjecaj su ušli nazivi gradišćanski / Gradišćanski Hrvati i gradišćanskohrvatski jezik. Osim Hrvata u Austriji taj su naziv prihvatili i hrvatski žitelji desetak sela na krajnjem zapadu Republike Mađarske (Koljnof / Kópháza, Umok / Fertőhomok, Vedešin ili Hedešinci / Hídegség, Hrvatska Kemlja / Horvátkimle, Bizunja / Bezenye, Unda / Und, Prisika / Peresznye, Plajgor / Olmód, Hrvatski Židan / Horvátzsidány, Temerje / Tömörd, Mala Narda / Kisnard, Velika Narda / Nagynard, Donji Čatar / Alsó Csatár, Gornji Čatar / Felsö Csatár, Hrvatske Šice / Horvatlövő, Petrovo Selo / Szentpéterfa) i u gradovima Šopron / Sopron, Kiseg / Köszeg, Sambotel / Szombathely i Körmend. Pripadnici hrvatske manjine u Republici Slovačkoj (Rosvar / Rusovce, Hrvatski Jandrof / Jarovce, Čunovo, Hrvatski Grob / Chorvátski Grob, Devinsko Novo Selo / Devínska Nová Ves) s tim se etnonimom uglavnom ne identificiraju kao ni potkraj četrdesetih godina XX. stoljeća prisilno raseljeni pripadnici hrvatske etničke zajednice u Republici Češkoj. 
Između dvaju svjetskih ratova, s novim etnonimom i u novim državnim granicama u trima državama (Austriji, Mađarskoj i Čehoslovačkoj) središte će kulturne djelatnosti gradišćanskih Hrvata biti u Austriji. Tradira se gradišćanskohrvatski književni jezik čakavske osnovice. Kad su god. 1923. pokrenute „Hrvatske novine” (izlazile do 1940.) kao nestranačko glasilo, zalaganjem Ignaca Horvata (1985.-1973.) postale su one i ,škola stvaranja i njegovanja lašćeg književnog jezika”. Tomu su pripomogle školske knjige (štanke) za pouku gradišćanskohrvatskoga: Andrija Kuzmić (Kuzmich), Jožef Pajrić (Payrich): Početnica i perva štanka (Sopron 1923; Beč / Leipzig ${ }^{2}$ 1932), Ivan Dobrović (Dobrovich): Druga štanka za horvatske narodne škole (Beč / Leipzig 1926), Ivan Dobrović: Treta štanka (Beč / Leipzig 1926).

Oslanjajući se na koncepciju pravopisnoga priručnika Dragutina Boranića (Boranić 1921), Horvat je sastavio „fonološki” koncipiran prvi pravopisni priručnik gradišćanskohrvatskoga (Horvat 1940?).

Ipak, i nakon odluke da razvijaju vlastiti književni jezik čakavske osnovice, nisu posve nestale sve dvojbe o opravdanosti toga izbora. Razvidno je to npr. iz pisma koje je Ignac Horvat 16. veljače 1937. uputio Stjepanu Ivšiću u kojem ga pita: „1. Da li je - iz jezičnog pogleda - pametno, ako mi ostajemo uz naš čakavski (govor) jezik, kojega i Vi već dobro poznajete? 2. Ima li smisla, da mi saberemo naše riječi te izdamo - za našu inteligenciju - jedan rječnik naših književnih riječi?" (Ivšić 1937/1971: 766). Pozitivan Ivšićev odgovor na oba pitanja svakako je znatno više od kurtoazne podrške.

Nažalost, posve drugačije, neusporedivo nepovoljnije prilike nastupile su nakon pripojenja (Anschluss) Austrije Trećemu Carstvu (Reichu) 13. ožujka 1938. i tako je ostalo do kraja Drugoga svjetskog rata.

Iako su prvi parlamentarni izbori u Austriji nakon Drugoga svjetskog rata održani 25. studenog 1945., saveznički okupacijski režim potrajao je sve do 25. svibnja 1955. kad je potpisan Državni ugovor između Austrije i velikih sila kojim je Austrija postala neovisna republika u granicama kakve je imala u početku god. 1938. U pet stavaka 7. članka toga ugovora u načelu su regulirana sva prava slovenske i (gradišćansko)hrvatske manjine u Republici Austriji od građanske ravnopravnosti i prava školovanja na vlastitome jeziku do podizanja manjinskih jezika na razinu regionalnih uredovnih jezika i dvojezičnih naziva mjesta. 
Usprkos činjenici da se austrijske vlasti nisu baš žurile oživotvoriti spomenute ugovorne odredbe, postupno se, od kraja četrdesetih godina, pristupilo ,jezičnoj reformi” ili, točnije, rekodifikaciji gradišćanskohrvatskoga književnog jezika (cf. npr. rubriku Jezični kut u „Hrvatskome tajedniku"; izlazio od 1947. do 1960.) koji se tako, dobivajući na polifunkcionalnosti, via facti postupno odmicao od čakavskih organskih idioma (mjesnih govora).

Šezdesete godine donose zadnji val podrške hrvatskomu književnom jeziku. Nositelji su mu pripadnici tada mladoga književnog naraštaja povezanog s Hrvatskim akademskim klubom (HAK; osnovan u Beču 1948.), što u svom časopisu „Glas” (izlazio od 1957. do 1963.) elaboriraju ovako:

Naša najveća zadaća, naš cilj, pa ako hoćete, da to nazovem programom, jeste, da polako sprovodimo hrvatski književni jezik u naš hrvatsko-gradišćanski prostor. Zadaća naše nove generacije mora se sastojati u tome, da mi evolucionim putem prihvatimo hrvatski književni jezik i da ga prilagodimo našoj nacionalnoj manjini, kao književni jezik svih danas živućih Hrvata (Kinda-Berlaković 2011: 384).

S njima se koncepcijski slažu i tadanji nadzornici za hrvatske škole u Gradišću Rudolf Klaudus i Konrad Meršić (autor vježbenice i gramatike Naš jezik; Beč, 1964). Tih je godina pitanje o gradišćanskohrvatskome književnom jeziku pobudilo zanimanje i autora izvan Gradišća (cf. Vasilev 1966).

Preokret u razmišljanjima o književnome jeziku gradišćanskih Hrvata nagovijestio je referat koji je Josip Hamm održao na znanstvenome skupu u prigodi 25. obljetnice osnivanja HAK-a. Bilo je to prvi put da je gradišćanskohrvatsko jezično stanje promotreno u slavističkim okvirima i uspoređeno s poznatim „malim” slavenskim jezicima (obama lužičkosrpskima i kašupskim). Ta je usporedba pokazala da se gradišćansko jezično stanje s obzirom na četiri odabrane značajke (1. prostor, 2. vrijeme, 3. popratne okolnosti i 4. osnovu) odlikuje nizom različitosti i osebujnosti ne samo prema spomenutim slavenskim jezicima nego i prema moliškohrvatskomu istonacionalnom analogonu. „Iz svega, ča je rečeno, moremo viditi, da gradišćansko-hrvatski jezik nije neki novi ili drugačiji slavenski jezik, koga bi mogli strukturalno kao jezik jednake vridnosti prispodobiti s drugim slavenskim jezikom - nit sa lužičko-srpskim" (Hamm 1974: 49). Potom se ističe činjenica da je gradišćanskohrvatsko stanje most od hrvatske jezične starine prema živoj osnovi za proučavanje nekih slavistici važnih pojava: 
Za istraživanje slavenske diftongizacije je kumaj tako obiljno ko drugo jezično područje kao gradišćansko-hrvatski jezik. Isto valja i za naglasak, ki pruža uvijek nove aspekte i još uvijek nije iscrpljen do zadovoljavajuće mjere, za sintaksu, u koj je još sve živo i u ku se intonacija riči uklapa bez teškoće (Hamm 1974: 51).

Tu živost gradišćanskohrvatskoga Hamm je istaknuo i u predavanju koje je 14. ožujka 1974. održao u Hrvatskome akademskom klubu dodavši „da je baš na osnovi dijalekatskih razlika nužno stvoriti jedan zajednički gradišćanskohrvatski književni jezik i to u trenutku njegove 470 godišnje tradicije postojanja" (cf. Benčić 1998b: 261).

Nakon toga novi je zamah dobio projekt izradbe dijalektnoga (Palkovits 1987) i normativnoga rječnika gradišćanskohrvatskoga jezika inicirana na početku sedamdesetih koji je 1972. uvršten u međudržavni ugovor između SR Hrvatske i pokrajine Burgenland / Gradišće. Na tom su leksikografskome poslu zajednički radili predstavnici gradišćanskih Hrvata, Instituta za slavistiku Sveučilišta u Beču i Instituta za jezik JAZU iz Zagreba. Tako su izrađena dva trojezična rječnika: jedan s gradišćanskohrvatskim književnim jezikom kao jednim od ciljnih jezika (Bencsics, Finka, Šojat, Vlasits, Zvonarich 1982), drugi s gradišćanskohrvatskim kao polaznim jezikom (Lončarić, Seedoch 1991). Rad na tim rječnicima išao je naruku drugomu od triju rješenja „zapletena jezičnog položaja gradišćanskih Hrvata” o kojima je govorio Radoslav Katičić: „Standardiziran gradišćanskohrvatski književni jezik dobro bi odgovarao gradišćanskim Hrvatima, vrlo bi živo izražavao tradiciju i duhovne vrijednosti koje oni nose i kojima su intimno obvezani, a potirao bi sve slabosti i gubitke što proizlaze iz isključive porabe njemačkoga standardnog jezika" (Katičić 1983/1992: 162). U nastavku upravo takvih nastojanja u devedesetima objavljen je prvi, opsegom skromniji (usporedni) pregled gramatike (Berlaković 1995), a nešto poslije i opsežna Gramatika gradišćanskohrvatskoga jezika na kojoj je od 2001. radilo desetak hrvatskih, gradišćanskohrvatskih i austrijskih suradnika/ca (Sučić 2003). Najzad, prije nekoliko godina dovršen je i objavljen Pravopis gradišćanskohrvatskoga književnoga jezika četiriju autor(ic)a (Sučić 2009).

Nakon što je poslije drugoga vatikanskog sabora gradišćanskohrvatski postao jedan od obrednih jezika Katoličke crkve, uz dugu i bogatu vlastitu rukopisnu baštinu (cf. npr. Nyomárkay, Vig 2005) i tradiciju izdavanja različitih vjerskih i vjersko-poučnih djela, pučkih kalendara, etničkih 
novina i časopisa, čitanki i drugih školskih knjiga namijenjenih gradišćanskim Hrvatima, god. 1979. započelo je redovito emitiranje radijskih emisija na gradišćanskohrvatskome. God 1987. gradišćanskohrvatski je pokusno uveden u gimnazije i postao drugim službenim jezikom Burgenlanda / Gradišća. Nedugo potom (1989.) radijskima su se pridružile televizijske emisije na gradišćanskohrvatskome, a 1992. otvorena je dvojezična savezna gimnazija u Borti / Oberwart. (God. 1994. osnovan je Znanstveni institut Gradišćanskih Hrvatov - ZIGH). Te su nove sociolingvističke prilike i komunikacijske potrebe upravo silile na „dogradnju” gradišćanskohrvatskoga književnog jezika, ponajprije u području leksika i nazivlja, za što mu je hrvatski jezični standard dobar uzor i bogato vrelo, jer bez toga ne bi bio osposobljen za posredovanje većine sadržajā iz suvremenoga života. Tako je postalo očito da standardizacija, kao što je upozoravao Katičić, nije ni lagan ni jednostavan posao, nego da je posao koji ima svoju cijenu, materijalnu, ali i u obliku odricanja od spontanosti i stečenih jezičnih navika i svjesna napora koji je nužno uložiti u stjecanje novih. A da tu ima nedoumica i poteškoća, potvrđuju i radovi koji fokusiraju upravo gradišćanskohrvatsku kodifikacijsku i standardološku problematiku (Weilguni 1984; Szuczich 2000; Ślęzak 2006; Sučić 2008; Kinda-Berlaković 2011) koja bi, unatoč objavljenim temeljnim priručnicima, zbog mjestimičnih ,poroznosti” (npr. u prozodiji i ortoepiji) kodificirana modela i ubuduće, bar u dijelu gradišćanskohrvatske zajednice, vjerojatno mogla nailaziti na poteškoće u prihvaćanju i primjeni, a naravno i u njegovu kultiviranju.

Iz izloženoga je razvidno da je naziv gradišćanskohrvatski jezik (njem. burgenländischkroatische / burgenlandkroatische Sprache, mađ. gradistyei nyelv / burgenland horvát nyelv) nastao tek na početku dvadesetih godina XX. stoljeća, kao i da je punu afirmaciju u jezikoslovnoj kroatistici i slavistici stekao tek nakon Drugoga svjetskog rata. Taj naziv nije jednoznačan jer se upotrebljava: 1. retroaktivno kao naziv za jezik pismenosti (Schriftsprache) Hrvata na zapadnougarsko-austrijskome prostoru od XVI. do polovice XIX. stoljeća; 2. također retroaktivno za jezik književnosti i pisane kulture (Literatursprache) od polovice XIX. stoljeća do početka dvadesetih godina XX. stoljeća; 3. kao terminološki hiperonim za ukupnost idioma (varijeteta) kojima govore ili su u prošlosti govorili gradišćanski Hrvati i 4. kao naziv za standardizirani idiom (Standardsprache) 
ograničene polifunkcionalnosti svjesno oblikovan od dvadesetih godina XX. stoljeća kojim se danas gradišćanski Hrvati služe u javnoj pisanoj i govorenoj komunikaciji u Gradišću, zapadnoj Mađarskoj i, djelomično, u Republici Slovačkoj.

\section{Literatura}

Adamček J.,1995, Iseljavanje Hrvata u austrijsko-ugarski granični prostor, u: Povijest i kultura gradišćanskih Hrvata, ur. I. Kampuš, Zagreb, str. 13-30.

Balaž J., 1991, Hrvatski dialekt u Devinskom Novom Selu, Devinsko Novo Selo.

Bencsics N., Finka B., Šojat A., Vlasits J., Zvonarich S., 1982, Deutsch-burgenlandkroatisch-kroatisches Wörterbuch - Nimško-gradišćanskohrvatsko-hrvatski rječnik, Eisenstadt-Zagreb.

Benčić N., 1972, Abriß der geschichtlichen Entwicklung der burgenländischkroatischen Schriftsprache, „Wiener slavistisches Jahrbuch” br. 17, str. 15-28.

Benčić N., 1995, Pismo i književnost, u: Povijest i kultura gradišćanskih Hrvata, ur. I. Kampuš, Zagreb, str. 218-276.

Benčić N., 1998a, Književnost gradišćanskih Hrvata od XVI. stoljeća do 1921., Zagreb.

Benčić N., 1998b, Gradišćanski Hrvati, u: Hrvatski jezik, ur. M. Lončarić, Opole, str. 249-270.

Benčić N., 2006, Krivudanja gradišćanskohrvatskoga jezika u 20. stoljeću, u: Hrvatski jezik u XX. stoljeću, ur. M. Samardžija, I. Pranjković, Zagreb, str. 265-274.

Berlaković M., 1995, Mali pregled gramatike gradišćanskohrvatskoga i hrvatskoga jezika (usporedna gramatika), Großpetersdorf-Veliki Borištof.

Boranić D., 1921, Pravopis hrvatskoga ili srpskoga jezika, Zagreb $\left[{ }^{2} 1923 .,{ }^{3} 1926\right.$. , ${ }^{4}$ 1928. Ponovljeno 4. izdanje: Zagreb 1940].

Botík J. (ur.), 1999, Charvátska národnost’ na Slovensku. História, onomastika, národopis, Bratislava.

Botík J., 2001, Slovenský Chorváti. Etnokultúrni vývin z ných pohl'adu spoločenskovedných poznatkov, Bratislava.

Brabec I., 1973, Hrvatski govori u Gradišću, u: Gradišćanski Hrvati, ur. Z. Črnja, M. Valentić, N. Benčić, Zagreb, str. 61-90.

Breu J., 1970, Die Kroatensiedlung im Burgenland und in den anschließenden Gebieten, Wien.

Breu J., 1995, Prostorni opseg i posljedice za sliku naselja, u: Povijest i kultura gradišćanskih Hrvata, ur. I. Kampuš, Zagreb, str. 43-104.

Csaplovics J., 1829, Croaten und Wenden in Ungarn. Etnographisch geschildert, Pressburg.

Črnja Z., Valentić M., Benčić N. (ur.), 1973, Gradišćanski Hrvati, Zagreb.

Duličenko A.D., 1976, O položaju suvremenog gradišćanskohrvatskog književnog jezika u Austriji, „Čakavska rič” god. VI, br. 1, str. 35-63. 
Duličenko A.D., 1981, Slavjanskie literaturnye mikrojazyki (Voprossy formirovanija i razvitija), Tallin.

Duličenko A.D., 1994, Kleinschriftsprachen in der slawischen Sprachenwelt, „Zeitschrift für Slawistik" br. 39, str. 560-567.

Finka B., 1984, Gradišćanskohrvatska jezična kodifikacija u Nimško-gradišćanskohrvatsko-hrvatskom rječniku, u: Gradišćanski Hrvati 1533.-1983. (zbornik), ur. B. Finka, str. 109-119, Zagreb.

Hadrovics L., 1974, Schrifttum und Sprache der burgenländischen Kroaten im 18. und 19. Jahrhundert, Budapest.

Hadrovics L., 1995, Povijest gradišćanskohrvatskoga književnog jezika, u: Povijest i kultura gradišćanskih Hrvata, ur. I. Kampuš, Zagreb, str. 465-485.

Hamm J., 1974, Položaj i značaj gradišćanskohrvatskog jezika unutar slavenske jezične grupe, u: Symposion Croaticon. Gradišćanski Hrvati / Die Burgenländischen Kroaten, ur. F. Palkovits, „Publikacije” br. 1, str. 45-52.

Horvat I., 1940?, Kratak pravopis. Sastavio po dr. D. Boraniću i[gnac] h[orvat], S.1. [Šapirografirano].

Horvath Š., 1998, Rani gradišćanskohrvatsko-ugarski rječnik, „Gradišćanskohrvatske studije" br. 3, Željezno / Eisenstadt.

Ivšić S., 1937/1971, Hrvatska dijaspora u 16. stoljeću i jezik Hrvata Gradišćanaca. Priredio i dijelom obradio B. Finka, u: Izabrana djela iz slavenske akcentuacijeGesammelte Schriften zum slavischen Akzent. Mit einer Einleitung sowie Berichtigungen und Ergänzungen des Verfassers herausgegeben von Christiaan Alphonsus van den Berk, „Slavische Propyläen” br. 96, München, str. 723-798.

Jembrih A., 1997, Na izvori gradišćanskohrvatskoga jezika i književnosti - Aus dem Werdegang der Spache und Literatur der Burgenlandkroaten, ,Gradišćanskohrvatske studije" br. 1, Željezno / Eisenstadt.

Kampuš I. (ur.), 1995, Povijest i kultura gradišćanskih Hrvata, Zagreb.

Katičić R., 1983/1992, Lingvističke dimenzije jezičnoga položaja gradišćanskih Hrvata, u: Novi jezikoslovni ogledi. Drugo, dopunjeno izdanje, Zagreb, str. 158-164.

Kinda-Berlaković Z., 2011, Razvojni put književnog jezika gradišćanskih Hrvata do regionalnog hrvatskog standardnog jezika, „Croatica et Slavica Iadertina” br. 7, str. 377-387.

Kolarič R., 1973, Govor dveh slovenskih vasi ob Nežiderskom jezeru, „Južnoslovenski filolog" br. 30, str. 369-381.

Koschat H., 1978, Die čakavische Mundart von Baumgarten im Burgenland, Wien.

Kučerová K., 1998, Hrvati u srednjoj Europi, Zagreb [Prvo izdanje: Chorváty a Srbi v strednej Europe, Bratislava 1976].

Kurelac F., 1871, Jačke ili narodne pěsme prostoga i neprostoga puka hrvatskoga po župah Šoprunskoj, Mošonjskoj i Želěznoj na Ugrih, Zagreb.

Lončarić M., Seedoch I. (izd.), 1991, Burgenländischkroatisch-kroatisch-deutsches Wörterbuch - Gradišćanskohrvatsko-hrvatsko-nimški rječnik, Zagreb-Eisenstadt.

Maretić M., 1899, Gramatika hrvatskoga jezika za niže razrede srednjih škola, Zagreb [21901.] - Hrvatska ili srpska gramatika za srednje škole, Zagreb, ${ }^{3}$ 1906., ${ }^{4} 1913 .,{ }^{5} 1918$. 
Neweklowsky G., 1978, Die kroatischen Dialekte des Burgenlandes und der angrenzenden Gebiete, Wien.

Neweklowsky G., 1989, Der kroatische Dialekt von Stinatz. Wörterbuch, Wien.

Neweklowsky G., 1995, Hrvatska narječja u Gradišću i susjednim krajevima, u: Povijest i kultura gradišćanskih Hrvata, ur. I. Kampuš, Zagreb, str. 431-464.

Neweklowsky G., 2008, Gradišćansko-hrvatski jezik kao sistem. Referat prilikom 25. obljetnice Nimško-gradišćanskohrvatsko-hrvatskoga rječnika, Virtualni časopis ZIGH, 15.10.2014.

Neweklowsky G., 2010, Die Sprache der Burgenländer Kroaten-Jezik Gradišćanskih Hrvatov, „Gradišćanskohrvatske studije” br. 7.

Nyomárkay I., 1996, Sprachhistorisches Wörterbuch des Burgenlankroatischen mit einem rückläufigen Verzeichnis der Titelwörter, Eisenstadt-Budapest.

Nyomárkay I., Vig I., 2005, Rukopisne prodike iz Pannonhalme, Željezno / Eisenstadt.

Pálffi G., Pandžić M., Tobler F. (prir.), 1999, Ausgewählte Dokumente zur Migration der Burgenländischen Kroaten im 16. Jahrhundert, Eisenstadt / Željezno.

Palkovits E., 1987, Wortschatz des Burgenlandkroatischen. Schriften der Balkankomission. Linguistische Abteilung, Wien.

Pavličević D., 1994, Moravski Hrvati. Povijest - život - kultura, Zagreb.

Sučić I.L., 1973, Dijalekti i književnost Gradišćanskih Hrvata, u: Gradišćanski Hrvati, ur. Z. Črnja, M. Valentić, N. Benčić, Zagreb, str. 91-95.

Sučić I. (ur.), 2003, Gramatika gradišćanskohrvatskoga jezika, Željezno / Eisenstadt.

Sučić I., 2008, Normiranje gradišćanskohrvatskoga književnoga jezika u rječniku, gramatiki $i$ pravopisu, <http://www.zigh.at/index.php?id=22\&tx_ttnews[tt_news]= $38 \& \mathrm{cHash}=\mathrm{c} 7058763 \mathrm{abce} 4 \mathrm{f9cb98e701af5984c66>,12.10.2014.}$

Sučić I. (ur.), 2009, Pravopis gradišćanskohrvatskoga književnoga jezika, Eisenstadt.

Szuczich L., 2000, Das Burgenlandkroatische: Sprachwandel, Sprachverfall, Sprachverschiebung und Sprachassimilation, u: Sprachwandel in der Slavia. Die slavischen Sprachen an der Schwelle zum 21. Jahrhunderts, ur. L. Zybatow, Frankfurt, str. 853-875.

Ščukanec A., 2011, Njemačko-hrvatski jezični dodiri u Gradišću, Zagreb.

Ślęzak A., 2006, Burgenlandzcy Chorwaci i ich tradycje językowe, Bielsko-Biała.

Šojat A., 1980/1981, O jeziku i rječniku gradišćanskih Hrvata, „Rasprave Zavoda za jezik IFF" br. 6-7, str. 305-317.

Takač F., 2004, Rječnik sela Hrvatski Grob, Zagreb.

Tornow S., 1971, Die Herkunft der kroatischen Vlahen des südlichen Burgenlands, t. 39, Veröffentlichungen der Abteilung für slavischen Sprachen und Literaturen, Berlin.

Tornow S., 1989, Burgenländischkroatisches Dialekt-Wörterbuch. Die vlahischen Ortschaften, „Balkanologische Veröffentlichungen” br. 15, str. 409-414.

Tornow S., 2011, Burgenlandkroatische Dialekttexte, Wiesbaden.

Tyran K., 2010, Das klingenbacher handschriftliche Fragment - Klimpuški rukopisni fragment, „Gradišćanskohrvatske studije” br. 6, Trausdorf, str. 183-194.

Ujević M., 1934, Gradišćanski Hrvati, Zagreb. 
Valentić M., 1970, Gradišćanski Hrvati od 16. stoljeća do danas, Zagreb.

Valentić M., 1973, Novija povijest gradišćanskih Hrvata, u: Gradišćanski Hrvati, ur. Z. Črnja, M. Valentić, N. Benčić, Zagreb, str. 15-39.

Vasilev Ch., 1966, Die heutige čakavische Schriftsprache der Burgenland-Kroaten, u: „Aufsätze zur slavischen Philologie” br. 8, str. 189-233.

Vážný V., 1925, O chorvátskem „,kajkavskem” nářeči Horvátskeho Grobu. u: Podunajská dedina v Československu, ur. A. Vaclavík, Bratislava, str. 111-176.

Vážný V., 1927, Čakavske nářečí v slovenském Podunaji, „Sbornik Filosofické fakulty Universitý Komenského" br. 47, str. 121-336.

Vince Z., 1978 ( $\left.{ }^{2} 1990,{ }^{3} 2002\right)$, Putovima hrvatskoga književnog jezika. Lingvističkokulturnopovijesni prikaz filoloških škola i njihovih izvora, Zagreb.

Vulić S., Petrović B., 1999, Govor Hrvatskoga Groba u Slovačkoj, Zagreb.

Weilguni W., 1983, Soziolinguistische Aspekte der burgenländisch-kroatischen Sprachsituation, „Wiener slavistisches Jahrbuch” br. 29, str. 105-111.

Weilguni W., 1984, Die Diskussion um die Standardsprache bei den Burgenländerkroaten. Sprachpolitische und kulturpolitische Tendenzen seit der Mitte des 19. Jahrhunderts, dissertation, Wien. 